\title{
Cittaslow Hareketi'nin Geleneksel Türk Şehirleri’nde Sürdürülebilirlik Açısından Değerlendirilmesi
}

\author{
Esma AYAZ ${ }^{\mathrm{a} 1, *}$, Zeynep KEREM ÖZTÜRK ${ }^{\mathrm{a} 2}$, \\ a İstanbul Sabahattin Zaim Üniversitesi, Mühendislik ve Doğa Bilimleri Fakültesi, Mimarlık Yüksek Lisans, İstanbul, Türkiye \\ İstanbul Sabahattin Zaim Üniversitesi Fen Bilimleri Enstitüsü Dergisi (2022) 4 (1): 1-13 \\ https://doi.org/10.47769/izufbed.1050655 \\ (iD) ORCID ${ }_{1}^{1} 0000-0003-1582-6422^{2} 0000-0001-7691-9126$
}

\begin{tabular}{|c|}
\hline YAYIN BİLGİSİ \\
\hline Yayın geçmişi: \\
\hline Gönderilen tarih: 29 Aralık 2021 \\
\hline Kabul tarihi: 4 Şubat 2022 \\
\hline Anahtar kelimeler: \\
\hline Cittaslow Hareketi \\
\hline Cittaslow Standartları \\
\hline Geleneksel Türk Şehirleri \\
\hline Küreselleşme \\
\hline
\end{tabular}

\begin{abstract}
ÖZET
Son yıllarda küreselleşmenin de etkisiyle şehirlerde meydana gelen hızlı dönüşümler, yerel değerlerin unutulmasına, doğal çevrenin tahribatına yol açmıș ve açmaya devam etmektedir. Bu noktada sürdürülebilir kentleşme kavramı ve bu hedefe uygun kentsel planlamaların geliştirilmesi, önemli bir konu haline gelmiștir. Küreselleşmenin dayattı̆ğ tek tip şehirleşmeye tepki olarak ortaya çıkan görüşlerden biri de, Uluslararası Cittaslow Hareketi'dir. 1999 yılında İtalya'da kurulan birlik, nüfusu 50.000 'den az olan küçük yerleşimlerde yerel kimliklerin korunarak yaşam kalitesinin artırılmasını hedefleyen, üyelik için çeşitli kriterleri olan, sürdürülebilir ve çok katmanlı bir şehir modeli sunmaktadır. Özellikle özgün şehir dokusuna sahip geleneksel şehirlerde, şehirleşme yapısı ve mimari özelliklerin gelecek kuşaklara aktarılması noktasında sürdürülebilirliğin sağlanması oldukça önemlidir. Geleneksel Türk Şehri'nin sürdürülebilirlik ilkeleri açısından incelenmesi, bu özelliklerin geliştirilerek bugünün sürdürülebilir çağdaş planlama ve tasarım anlayışına ipuçları vermesi bu çalışmanın ana amaçlarından birisidir. Bu doğrultuda, geleneksel şehir yapılanmalarındaki sürdürülebilirlik etkileri, Cittaslow standartları bağlamında ele alınarak değerlendirilmiştir. Amacı küreselleşmenin etkilerine karşı küçük şehirlerde, yerel kimliği koruyarak sürdürülebilirliği sağlamak olan Cittaslow Hareketi'nin, bu amaca ulaşılması konusunda ne kadar etkili olduğu sorunsallaştırılmış, olumlu yanlarının yanında, olumsuz olabilecek sonuçlarına da yer verilmiş̧ir
\end{abstract}

\section{Evaluation of The Cittaslow Movement in Terms of Sustainability in Traditional Turkish Cities}

\begin{tabular}{l}
\hline ARTICLE INFO \\
\hline Article history: \\
Received: 29 December 2021 \\
Accepted: 4 February 2022 \\
\end{tabular}

\section{Key words:}

Cittaslow Movement

Cittaslow Standarts

Traditional Turkish Cities

Globalization

Sustainable

\begin{abstract}
The rapid transformations that have taken place in cities with the effect of globalization in recent years have led to the forgetting of local values and the destruction of the natural environment which still continues to do so. With regards to this, the concept of sustainable urbanization and the development of urban planning aimed to achieve this goal have become an important issue. One of the views that emerged as a reaction to the uniform urbanization imposed by globalization is the International Cittaslow Movement. Founded in Italy in 1999, the union offers a sustainable and multi-layered city model with various criteria for membership, aiming to increase the quality of life by preserving local identities in small settlements with a population of less than 50,000. It is very important to ensure sustainability in terms of transferring urbanization structure and architectural features to future generations, especially in traditional cities with a unique urban texture. One of the main purposes of this study is to examine the traditional Turkish city in terms of sustainability principles, to develop these features that will serve as a means to give clues to today's sustainable contemporary planning and design understanding. In accordance with this, sustainability effects in traditional city structures were evaluated within the context of Cittaslow standards. The effectiveness of the Cittaslow Movement, whose aim is to ensure sustainability by protecting local identity in small cities against the effects of globalization, has been problematized in achieving this goal, and its positive aspects as well as its negative consequences are also included.
\end{abstract}

\section{Giriş}

Cittaslow ismiyle bilinen sakin şehir modeli, küreselliğin getirdiği hızlı hayata karşı bir tepki olarak İtalya' da ortaya çıkmıştır. Çevresel ve sosyal yönden birtakım sorunlar sebebi ile sürdürülemeyen günümüz modern şehir kavramına karşı geliştirilen, alternatif bir sürdürülebilir şehir modelidir. Cittaslow felsefesi temelde, küreselleşmeye karşı sürdürülebilir, adil ve eşit kentsel gelişimi savunurken, aynı zamanda kentlerin yerel kimliğinin korunarak kalkınması ve yaşam kalitesinin artırılmasını da desteklemektedir. 
Cittaslow kavramı dilimize "Sakin Şehir" ya da "Yavaş Şehir" olarak geçmiştir. Bu çalışmada kavram kargaşasını önlemek adına “Cittaslow” ifadesi kullanılmıştır. Küreselleşmenin kültürlerin alışverişinden doğan uluslararası bir bütünleşme süreci olarak olumlu sonuçların yanında, olumsuz sonuçları da beraberinde getirdiğini görmekteyiz. Küreselleşme mantığına göre sürekli olarak büyümesi gereken kentler, şüphesiz ki bu olumsuz sonuçlardan en çok etkilenen yerler olmuşlardır. Kentler küreselleşme ile köklü bir dönüşüme maruz kalmış, büyük kentlerdeki gelişim çabası, hayatın her alanına giren hız olgusu, kimliksiz yapılaşma, doğal kaynakların kontrolsüz tüketimi ile insanın çevreyi tehdidi ciddi boyutlara varmıştır. Buna paralel olarak sürdürülebilirlik perspektifinden bakılan, yeni kentsel planlama yaklaşımları gündeme gelmiştir. Yakın geçmişe kadar küreselleşmenin daha çok büyük kentler üzerindeki etkileri çalışmalara konu olurken, her geçen gün hızını ve etki alanını arttıran küreselleşme, küçük geleneksel şehirlerin uzun yıllar yaşatabildikleri değerlerine, hiç olmadığı kadar zarar vermiş, bu alanların sürdürülmesine yönelik çalışmaları gündeme getirmiştir. Bu yaklaşımlardan birisi olan Cittaslow kavramı da, sürdürülebilir çevre ve enerji odaklı geliştiren modellere farklı bir bakış açısı getirmiş, sürdürülebilir şehir kavramını, insan ve kimlik odaklı ele alıp, küçük şehirlerde yaşam kalitesini sürdürmeyi hedefleyen bir hareket haline gelmiştir. Cittaslow, çevresel ve etkin enerji kullanımına yönelik stratejilerin yanında, yerel bir kalkınma hedefi, özgün kimliğin korunması ve geleneklerin yaşatılması gibi politikalarıyla, küreselleşmeye yenik düşen küçük, geleneksel şehirlerin yaşatılabilmesi için sürdürülebilir alternatif bir model sunmaktadır.

\section{Materyal ve Yöntem}

$\mathrm{Bu}$ araştırma kapsamında konuyla ilgili literatür taramasında bulunulmuş, gerek ulusal gerekse uluslararası bilimsel kaynaklardan yararlanılmıştır. Kaynakların taramasıyla elde edilen veriler sonucu Cittaslow Hareketi kriterleri ve ülkemizdeki Cittaslow seçilen şehirlere ait kriterlerle birlikte, Cittaslow ünvanına sahip olmayan diğer Geleneksel Türk Şehirleri'nin genel anlamda dokuları ve kimlikleri karşılaştırılarak sürdürülebilirlik bağlamında söz konusu Cittaslow Hareketi ile karşılaştırması yapılmıştır.

\section{Sürdürülebilir Bir Yerel Kalkınma Modeli:Cittaslow}

Cittaslow ismiyle bilinen yavaş şehir modeli, küreselliğin getirdiği hızlı hayata karşı, çevresel ve sosyal yönden birtakım sorunlar sebebi ile sürdürülemeyen günümüz modern şehir kavramına karş1 geliştirilen bir şehir modelidir.1999 yılında Paolo Saturnini'nin öncülüğünde İtalya'da hıza karşı daha sakin bir yaşam şeklinin benimsenmesi ve yaşam kalitesinin artırılması gibi amaçlarla ortaya çıkmıştır. Felsefenin kökeni 1980 yılında ortaya çıkan Yavaş Hareketine dayanmaktadır. Daha sonraki süreçte Roma'da İspanyol Merdivenlerinin hemen yakınına açılan Mc Donalds şubesine karşı görüşlerin geliştirdiği Slow Food, Yavaş Hareketinin devamı, Cittaslow gibi yavaş hareketlerinin de öncüsü olmuştur. Yavaş felsefesi hayatın birçok alanında hızın kötü etkilerine karşıı bir hareket olarak benimsenmiş: yavaş mimari, yavaş turizm, yavaş eğitim, yavaş moda gibi birçok sosyal kavramda karşılık bulmuştur (Honore, 2008). Cittaslow kelime anlamı olarak incelendiğinde, Cittá (şehir) İtalyanca bir kelime ve Slow (yavaş / sakin) İngilizce bir kelimedir. Hareketin kökenine ve evrensel özelliğine vurgu yapmak için İtalyanca ile evrensel dil olan İngilizce bir arada kullanılmıştır (Doğan, 2015) (Karakaş Özür, 2016) .

Cittaslow hareketinin logosu "modern ve tarihi binaları taşıyan turuncu bir salyangoz" olarak tercih edilmiștir. Evrensel bir marka haline gelmeyi hedefleyen hareket, küreselleşme sonucu gelişen homojen tek tip mekânlara karşı, doğaya saygılı sürdürülebilir şehirleşmeyi savunmaktadır. Yerelliğini ve kimliğini koruyarak küresel sahnede yer almak isteyen nüfusu 50.000' in altındaki küçük şehirlerin katıldığı bir birlik haline gelmiştir. Birliğin Ulusal ve Uluslararası merkez şehri Orvieto'dur. "Cittaslow” ünvanı almak isteyen şehirlerin değerlendirilmesi ve sürecin takibi bu merkezden yürütülmektedir (www.cittaslow.org, 2020) (Üstün Topal, Korkut, \& Kiper, 2016) (Sezgin \& Ünüvar, 2011).

\subsection{Cittaslow Felsefesi}

Cittaslow Felsefesi hayatı ondan zevk alacak bir yavaşlıkta yaşamanın gerekli olduğunu savunmaktadır. İnsanların etkileşim halinde olduğu, sürdürülebilir, ekolojik çözümler içeren, kendi kendine yetebilen, yerel kültürün getirdiği tüm özelliklere sahip çıkan, yerel mimarinin ve yapım sistemlerinin korunduğu, teknolojik yeniliklerle entegre olmuş, altyapı sorunları çözülmüş, yenilenebilir enerji kaynaklarının kullanıldığı şehirlerin daha uzun ömürlü olacağı ve ideal şehir arayışına daha gerçekçi bir yaklaşım olacağı hedefiyle yola çıkmıştır (seferihisar.bel.tr, 2020).

Cittaslow en geniş anlamıla modern hayat biçimini ve bunun olumsuz etkilerini yıkacak kökten bir kültürel dönüşümün şehirler vasıtası ile gerçekleşmesini hedefleyen alternatif bir yerel yönetim modeli olarak tanımlanabilir. Cittaslow birliği küreselliğe topyekün karşı olmadığının, sadece küreselliğin getirdiği tek tipleşmeye karşı özgünlüğü ve yereli savunan bir hareket olduğunun özellikle üzerinde durmaktadır. Ne tam bir küresel, ne de yerel olan Cittaslow'un kü-yerel denilen kavramı yansıttığı söylenilebilir. 
Tablo 1: Cittaslow Kriterleri (https://cittaslowturkiye.org, 2020)

\begin{tabular}{|c|c|}
\hline Politikalar & Kriteler \\
\hline 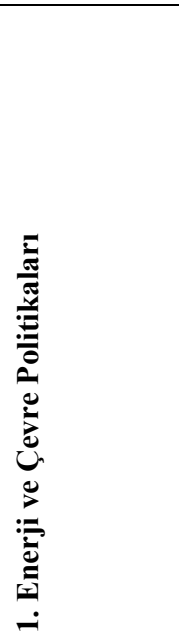 & $\begin{array}{l}\text { 1.1. Hava temizliğinin yasa tarafından belirtilen parametrelerde olduğunun belgelenmesi } \\
\text { 1.2. Su temizliğinin yasa tarafından belirtilen parametrelerde olduğunun belgelenmesi } \\
\text { 1.3. Halkın içme suyu tüketiminin ulusal ortalamayla karşılaştırılması } \\
\text { 1.4. Kentsel katı atıkların ayrıştırılarak toplanması } \\
\text { 1.5. Endüstriyel ve evsel kompostlamanın desteklenmesi } \\
\text { 1.6. Kentsel ya da toplu kanalizasyon için atık su arıtma tesisinin bulunması } \\
\text { 1.7. Binalarda ve kamu kullanım alanlarında enerji tasarrufu } \\
\text { 1.8. Kamunun yenilebilir enerji kaynaklarından enerji üretimi } \\
\text { 1.9. Görsel kirliliğin ve trafik gürültüsünün azaltılması } \\
\text { 1.10. Kamusal ışık kirliliğinin azaltılması } \\
\text { 1.11. Hane başına düşen elektrik enerjisi tüketimi } \\
\text { 1.12. Biyoçeşitliliğin korunması. }\end{array}$ \\
\hline 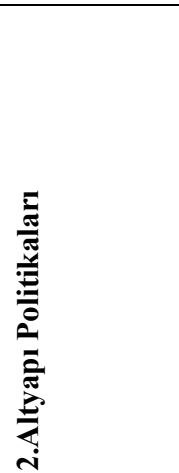 & $\begin{array}{l}\text { 2.1. Kamu binalarına bağlı verimli bisiklet yolları } \\
\text { 2.2. Mevcut bisiklet yollarının araç yollarıyla kilometre üzerinden karşılaştırılması } \\
\text { 2.3. Metro ve otobüs durakları gibi aktarma merkezlerinde bisiklet park yerleri } \\
\text { 2.4. Özel taşıt kullanımına alternatif olarak eko ulaşım planlanması } \\
\text { 2.5. Engellilere yönelik mimari engellerin kaldırılması } \\
\text { 2.6. Aile hayatı ve hamile kadınlar için girişimler } \\
\text { 2.7. Sağlık hizmetlerine onaylanmış ulaşılabilirlik } \\
\text { 2.8. Kent merkezlerinde malların sürdürülebilir dağıtımı } \\
\text { 2.9. Şehir dışında çalışan şehir sakinlerinin oranı }\end{array}$ \\
\hline 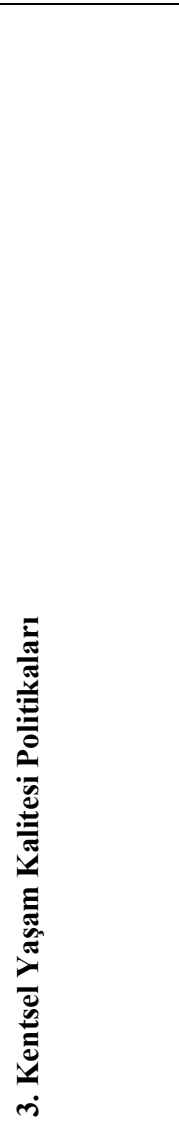 & $\begin{array}{l}\text { 3.1. Kentin direnci için planlama } \\
\text { 3.2. Kente ait değerlerin iyileştirilmesi, kent merkezlerinin ve kamu binalarının değerlerinin } \\
\text { arttırılması için programlar } \\
\text { 3.3. Verimli bitkiler ve meyve ağaçları kullanılarak sosyal yeşil alanların iyileştirilmesi } \\
\text { ve/veya oluşturulması } \\
\text { 3.4. Kentsel yaşanabilirliğin arttırılması } \\
\text { 3.5. Marjinal alanların tekrar değerlendirilip kullanılması } \\
\text { 3.6. Vatandaşlara ve turistlere yönelik interaktif hizmetlerin geliştirilmesinde bilgi ve } \\
\text { iletişim teknolojilerinden faydalanılması } \\
\text { 3.7. Sürdürülebilir mimari için hizmet masası oluşturulması } \\
\text { 3.8. Kentin internet ağına sahip olması } \\
\text { 3.9. Kirleticilerin izlenmesi ve azaltılması } \\
\text { 3.10. Tele çalışmanın geliştirilmesi } \\
\text { 3.11. Kişisel sürdürülebilir kentsel planlanmanın teşviki } \\
\text { 3.12. Sosyal altyapıyı desteklemek } \\
\text { 3.13. Kamusal sürdürülebilir kentsel planlamanın teşviki } \\
\text { 3.14. Kent içindeki kullanışlı yeşil alanların verimli bitkiler ile değerlendirilmesi } \\
\text { 3.15. Yerel ürünlerin ticarileşmesi için alanların yaratılması } \\
\text { 3.16. Atölyelerin korunması ve değerlerinin arttırılması - doğal/yerel alışveriş merkezlerinin } \\
\text { yaratılması } \\
\text { 3.17. Yeşil alanlarda kullanılan beton miktarı }\end{array}$ \\
\hline
\end{tabular}




\begin{tabular}{|c|c|c|}
\hline 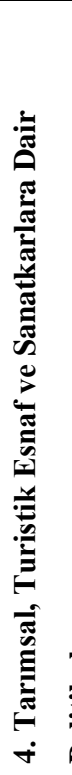 & 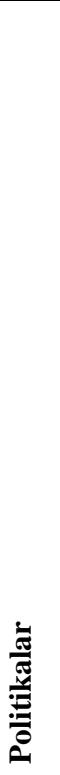 & $\begin{array}{l}\text { 4.1. Agroekolojinin geliştirilmesi } \\
\text { 4.2. El yapımı ve etiketli veya markalı esnaf/sanatkâr ürünlerinin korunması } \\
\text { 4.3. Geleneksel iş tekniklerinin ve zanaatların değerinin arttırılması } \\
\text { 4.4. Kırsal bölgede yaşayanların hizmetlere erişimini arttırarak kırsal bölgelerin değerini } \\
\text { arttırmak } \\
\text { 4.5. Kamuya ait restoranlarda (okul kantinleri, aş evleri vb) yerel, mümkünse organik } \\
\text { ürünlerin kullanılması } \\
\text { 4.6. Kişisel kullanımda ve yemek sektöründe tat eğitimlerinin verilmesi ve mümkünse } \\
\text { organik yerel ürünlerin kullanılmasının teşvik edilmesi } \\
\text { 4.7. Yerel ve geleneksel kültürel etkinliklerin korunması ve değerlerinin arttırılması } \\
\text { 4.8. Otel kapasitelerin arttırılması } \\
\text { 4.9. Tarımda GDO kullanımının yasaklanması } \\
\text { 4.10. Önceden tarım için kullanılmış alanların kullanımı hakkındaki imar planları için yeni } \\
\text { fikirlerin varlığı }\end{array}$ \\
\hline 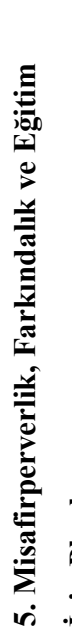 & 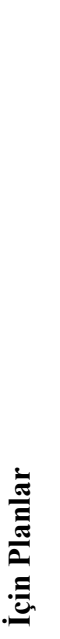 & $\begin{array}{l}\text { 5.1. İyi karşılama } \\
\text { 5.2. Esnafın ve operatörlerin farkındalıklarını arttırmak } \\
\text { 5.3. Yavaş güzergahların mevcut olması } \\
\text { 5.4. Önemli yönetimsel kararlara tabandan tavana katılım sürecini sağlayacak aktif } \\
\text { tekniklerin benimsenmesi } \\
\text { 5.5. Eğitimciler, yöneticiler ve çalışanların Cittaslow temaları hakkında sürekli eğitim } \\
\text { görmesi } \\
\text { 5.6. Sağlık eğitimleri } \\
\text { 5.7. Yöre halkına Cittaslow'un anlamı hakkında sistematik ve kalıcı eğitim vermek } \\
\text { 5.8. Cittaslow üzerine yerel yönetim ile çalışan derneklerin aktif varlığı } \\
\text { 5.9. Cittaslow kampanyalarının desteklenmesi } \\
\text { 5.10. Cittaslow logosunun internet sayfasında ve antetli kağı üzerinde kullanımı }\end{array}$ \\
\hline 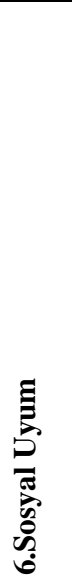 & & $\begin{array}{l}\text { 6.1. Azınlıklara yönelik ayrımcılığa karşı çalışmalar } \\
\text { 6.2. Farklı etnik kökene sahip insanların aynı mahallede yaşaması } \\
\text { 6.3. Engelli kişilerin entegrasyonu } \\
\text { 6.4. Çocuk bakımının desteklenmesi } \\
\text { 6.5. Genç neslin istihdam durumu } \\
\text { 6.6. Yoksulluk } \\
\text { 6.7. Toplumsal ortaklıklar/sivil toplum kuruluşların mevcudiyeti } \\
\text { 6.8. Farklı kültürlerin entegrasyonu } \\
\text { 6.9. Politikaya katılım } \\
\text { 6.10. Belediyenin kamu konut yatırımı } \\
\text { 6.11. Gençlik faaliyetlerinin yürütüldüğü bir alanların ve bir gençlik merkezinin mevcudiyeti }\end{array}$ \\
\hline 竞 & & $\begin{array}{l}\text { 7.1. Slowfood aktiviteleri ve kampanyaları için destek } \\
\text { 7.2. Doğal ve geleneksel yiyecekleri Slowfood veya diğer kurumlar ile desteklemek } \\
\text { 7.3. Eşleştirme projelerini desteklemek ve gelişmekte olan ülkelerin Cittaslow ve Slowfood } \\
\text { felsefelerinin yayılmasını da sağlayacak şekilde gelişmeleri için işbirliği yapmak }\end{array}$ \\
\hline
\end{tabular}




\subsection{Cittaslow Kriterleri}

Cittaslow'a üye olmak isteyen şehirler için uyulması gereken belirli kriterler bulunmaktadır. Nüfusu 50.000 altında olan şehirler, belediyelerin dahil olduğu bu birliğe üye olmak için 7 ana başlığ olan, 72 kritere uygunluğunu gösteren bir raporla ülkelerindeki Cittaslow temsilciğine başvuru yapabilmektedir. Ülkede Cittaslow temsilciği yoksa doğrudan uluslararası merkeze başvuru yapılabilmektedir. 7 genel başlık ve 72 kriter aşağıda belirtilmiştir:
- Enerji ve Çevre Politikaları ( 12 Madde)

- Altyapı Politikaları ( 9 Madde)

- Kentsel Yaşam Kalitesi Politikaları ( 17 Madde)

- Tarımsal, Turistik Esnaf ve Sanatkarlara Dair Politikalar (10 Madde)

- Misafirperverlik, Farkındalık ve Eğitim İçin Planlar( 10 Madde)

- Sosyal Uyum ( 11 Madde)

- Ortaklıklar ( 3 Madde)

Tablo 2: Yavaş Şehir Üyelik Kriterlerinin Sürdürülebilirlikle İlişkisi

\begin{tabular}{ccc}
\hline Yavaş Kent Üyelik Kriterlerinin Kategorileri & Kriterler & Sürdürülebilirlik Odaklı \\
\hline Enerji ve Çevre Politikaları & 12 & 9 \\
\hline Altyapı Politikalart & 9 & 7 \\
\hline Kentsel Yaşam Kalitesi Politikaları & 17 & 13 \\
\hline Tarımsal, Turistik Esnafve Sanatkarlara Dair Politikalar & 10 & 0 \\
\hline Misafirperverlik, Farkındalık ve Eğitim İçin Planlar & 10 & 5 \\
\hline Sosyal Uyum & 11 & 1 \\
\hline Ortaklıklar & 3 & $\mathbf{4 4}$ \\
\hline TOPLAM & $\mathbf{7 2}$ & \\
\hline
\end{tabular}

$\mathrm{Bu}$ çalışmada yukarıdaki tabloda verilen Cittaslow kriterlerinin doğrudan sürdürülebilirlikle ilgili olan maddeleri değerlendirmeye alınmıştır. Buna göre çevresel, ekonomik ve sosyal sürdürülebilirlik olarak üç kategoride incelenen kurallar şunlardır:

-Enerji ve çevre politikaları başlığı altındaki kriterlerden: Hava ve su temizliğinin yasa tarafından belirtilen parametrelerde olduğunun belgelenmesi, elektrik ve içme suyu tüketiminin kontrol altında tutulması, atıkların ayrıștırılmasının planlanması, arıtma tesisinin varlığı, yenilebilir enerji kaynaklarının kullanımı ve enerji tasarrufu olmak üzere 12 maddeden 9 tanesi çevresel sürdürülebilirliği destekler niteliktedir.

-Altyapı politikaları başlığı altındaki kriterlerden: yayalaştırma ve toplu taşımaya teşvik etme, bisiklet yollarının artırılması ve altyapısının sağlanması, eko ulaşım planları olmak üzere dokuz maddeden dördü çevresel sürdürülebilirliği destekleyen maddeler olurken: engelliler, sağlık hizmetleri ve aileye hayatı ile ilgili olan üç madde sosyal sürdürülebilirliğii: şehir içindeki ticaret altyapısını iyileştirme ve şehir dışında çalışan nüfusu azaltmaya yönelik 3 madde ekonomik sürdürülebilirliği destekler niteliktedir.

-Kentsel yaşam politikaları başlığı altındaki kriterlerden: verimli bitkilerin kullanılması kent peyzajına katk1 sağlaması, beton kullanımının en aza indirilerek yeşil oranının artırılması, kente özgü değerlerin ve mimarinin sürdürülebilirliğgi için girişimlerde bulunulması, sürdürülebilir kentsel tasarıma önem verilmesi, kirleticilerin en aza indirilmesi olmak üzere on yedi maddeden dokuzu çevresel sürdürülebilirliği desteklerken: yerel ürünlerin ticarileştirilmesi için uygun alanların oluşturulması ve yerel değerlerin üretimini artırmaya yönelik atölyelerin kurulmasına yönelik maddelerle ekonomik sürdürülebilirliği desteklemektedir.

-Tarımsal, Turistik Esnaf ve Sanatkarlara Dair Politikalar başlığı altındaki kriterlerden: agroekolojinin desteklenmesi ile geleneksel tarımın korunması, tarımda GDO kullanımının yasaklanması, tarım alanlarının kullanımı olmak üzere on maddeden dördü çevresel sürdürülebilirliği desteklerken: geleneksel meslek ve sanatların korunması ve geliştirilmesi, yerel kültürün korunması ve değerinin artırılmasına yönelik iki madde sosyal sürdürülebilirliği: el yapımı ürünlerin değerinin artırılması ve buna yönelik ticari merkezin kurulması, yemek sektöründe ve kişisel kullanımda yerele ait organik ürünlerin kullanımına yönelik maddeler ekonomik sürdürülebilirliği desteklemektedir.

-Misafirperverlik, Farkındalık ve Eğitim İçin Planlamalara dair politikalar başlığı altındaki kriterlerin konukları iyi karşılama çabaları, ziyaretçilere yönelik yavaş güzergahlarının tasarımı, turist 
rehberlerinin, esnafin ve halkın fiyatlarla ilgili şeffaf davranmalarına yönelik olması, sosyal ve ekonomik sürdürülebilirliği desteklemektedir.

-Sosyal Uyum Politikaları başlığı altındaki kriterlerden: farklı etnik kökenlerin aynı çevrede yaşaması, toplumsal ortaklık ve sivil kuruluşların olması, gençlik merkezlerinin mevcudiyeti, farklı kültürlerin entegrasyonu, engelli kişilerin entegrasyonuna yönelik maddelerle sosyal sürdürülebilirlik hedeflenmektedir.

Cittaslow modeli kriterleri incelendiğinde 72 maddeden 44'ünün doğrudan sürdürülebilirliğe hizmet eden maddeler olduğu söylenilebilir. \%61 oranında sürdürülebilirliğe yönelik hedefleri olan bu model öncelik olarak çevresel sürdürülebilirliği ardından sosyal ve ekonomik sürdürülebilirliği sağlamaya öncelik vermektedir. $\mathrm{Bu}$ sebeple bu şehir modelinin kentsel sürdürülebilirliği bir bütün olarak almasında dengeli bir yaklaşıma sahip olduğu görülmektedir.

\subsection{Cittaslow Yerleşimlerinin Sürdürülebilirlik Açısından Değerlendirilmesi}

Ülkemizdeki sakin şehirler incelendiğinde hemen her şehrin farklı coğrafyadan farklı özellikler taşıdığı görülmektedir. İklim özellikleri, tarihi kültürel özellikleri, geçmişten gelen medeniyet izleri herbirinde farklılık ve özgünlük göstermektedir. Cittaslow, bu farklı kültür ve iklim özelliklerine sahip şehirleri ortak bir platformda birleştirmiştir. Sakin şehirlerde birçok farklı yön ön plana çıksa da bu şehirleri özgün kılan birtakım ortak özellikler bir araya getirmiştir. Genellikle şehirlerde dikkat çeken ve sürdürülebilir şehir özelliklerinin birçoğunu destekler nitelikte olan ortak özellikler şu şekildedir:

- temiz ve el değmemiş bir doğa,

• sakin sosyal hayat, yürünebilir küçük mahalle sistemleri,

- tarıma ve hayvancılığa dayalı yerel bir ekonomi,

- yerel kültürün halen yaşatılıyor olması (yemek, kıyafet geleneksel el sanatları vb. )

• özgün mimari dokunun, yapım teknikleri ve malzemenin korunmuş olması,

• henüz bozulmamış sosyal ilişkiler,

$\mathrm{Bu}$ özelliklere bakıldığında ülkemizde bu 18 şehir dışında, aday olmasa dahi tarih, kültür, kimlik ve sakinlikleri ile Cittaslow felsefesinin pek çok kriterini rahatlıkla sağlayabilecek bir çok şehir sayılabilir. Ama bu özellikleri sağlıyor olsalar bile, Cittaslow olabilmek için teknoloji ile uyumlu ekolojik çözümler, altyapı ihtiyaçlarının giderilmesi, yaşam kalitesini artırmaya yönelik sürdürülebilir projeler üretmek gerekmektedir. Cittaslow Felsefesi'ne göre, özgün kültürel kimliğe sahip bu şehirler, doğal ve kültürel varlıklarını koruyarak isimlerini dünyaya duyurmayı hedeflemektedir. Böylece terkedilmiş, unutulmaya yüz tutmuş değerler bir farkındalıkla kıymeti bilinir hale gelebilmektedir. Örneğin: Taraklı'daki Geleneksel Osmanlı Konakları, Gökçeada'da Rum köylerinde bulunan özgün taş evler, Muğla'da Geleneksel Akyaya Evleri ve diğer şehirlere özgü birçok han, hamam, antik kent, lahitler, su yolları vb. kültür varlığı bu kapsamda restore edilerek çöküntü alanları olmaktan kurtulmakta ve böylece mimari sürdürülebilirlik sağlanmaya çalışılmaktadır. Ayrıca belediyelerin uygulamalarına bakıldığında bisiklet yolları yapılması, yenilenebilir enerji kullanımına yönelik çalışmalar yapılması sürdürülebilir ulaşımı, çevresel sürdürülebilirliği destekler niteliktedir. Seferihisar'da güneş enerjisi ile çalışan sokak lambaları ve bisikletlerin kullanılıyor olması, evsel ve endüstriyel kompostlama projelerinin olmas1, biogaz tesis projelerinin olmas1, GDO'lu ürünlerin yasaklanması, Tohum Takas Şenliği ile halkın teşvik edilmesi, kapalı pazar yerinde yapılan Güneş Enerji Santrali sayesinde 83 konutun enerji ihtiyacını karşılayabilecek elektrik üretilmesi gibi pek çok proje de sürdürülebilirlik ilkelerine yönelik uygulamalara örnek niteliğindedir.

Cittaslow markasına sahip olan şehirler elbetteki bir dönüşüm sürecine girmekte, sosyal, kültürel ve ekonomik yönden bir takım değişiklikler söz konusu olmaktadır. Bu değişimlerin ne yönde yapılmak istendiği ve nasıl şekilde sonuçlanacağı, özellikle yerel yönetimlerin ve halkın Cittaslow'u nasıl algıladığı ile ilgili bir durumdur. Cittaslow Felsefesi'nin doğru algılandığı takdirde, şehirlere sağlayacağı katkılar şu şekilde özetlenebilir:

- Çevre düzenlemesi, altyapı hizmetlerine önem verilmesi,

-Sosyal ve kültürel etkinliklerin artırılması ve canlılık kazandırılması,

-Sürdürülebilir şehir modelini destekleyen uygulamaların gerçekleştirilmesi,

- Bisiklet yollarının artırılması ile yürümeye teşvik etmesi,

- Yeni işletmelerin açılması dolayısıyla iş olanaklarındaki artış,

- Organik üretimin teşvik edilmesi,

- Geleneksel el sanatlarının, yerel mesleklerin yaşatılması nesilden nesile devam etmesi,

- Ev hanımlarına istihdam sağlanması,

- Halkın bilinçlenmesi, el emeğine, kültür varlığına ve çevreye verdiği önemin artması,

- Yöresel pazarlara ilginin artması, halkın gelirinin artması,

- Turizmdeki canlılığın esnafa ekonomik geri dönüşünün olumlu olmas1,

- Hava, su ve çevre kirliliğini azaltmaya yönelik bilincin gelişmesi,

- Yörenin, yerli ve yabancı birçok ziyaretçi tarafindan keşfedilmesi. Cittaslow seçilen şehirler genel anlamda dünya çapında olumlu bir imaja sahiptir. Ağa dahil olan kentler dünya çapında bilinen bir destinasyon haline gelmektedirler. Neredeyse tüm şehirler öncesine göre ilgi odağı olmakta ve ziyaretçi sayılarında artış yaşanmaktadır. 
TÜİK verilerine bakıldığında kayıtlı nüfusta ani değişimler olmasa da, kayıt dışı günübirlik ziyaretçi sayısında yoğun artış yaşandığı bilinmektedir. Cittaslow Uluslararası Başkan Yardımcısı Tunç Soyer de akademik çalışma için yapılan bir görüşmede, Cittaslow ilanından sonra artan kalabalık sonucu sakin şehir özelliğinin yitirilmesi konusunun, bir yandan sakin şehir olup diğer yandan çok insanın gelmesinin bıçak sırtı bir durum olduğunu kabul etmiş ve bunun dengede tutulması gerektiğinin, ikisinden de vazgeçilemeyeceğinin altını çizmiştir (Ayaz, 2021).

Türkiye'deki şehirlerden özellikle Seferihisar, Akyaka, Taraklı, Göynük ve Gökçeada'da ziyaretçi sayısında deniz turizmi, kaplıca ve sağlık turizmi, büyük şehirlere yakın olma gibi avantajlar sebebi ile yoğun artış görülmektedir. Bunda tur programlarının kitle turizminin etkisi yüksektir. Bu durum her ne kadar ekonomik getirisi sebebi ile yerel yönetimlerin ve halkın istediği bir durum olsa da kontrol atına alınmadığı takdirde meydana gelebilecek olumsuzluklar göz ardı edilemeyecek kadar önemlidir. Mevcut yaşam kalitesine olumsuz etkisi, altyapının bu sirkülasyon için yetersiz kalması, çevre kirliliği, gelen araç sayısının fazla olması sebebi ile karbon salınımının artması gibi etmenler hem sürdürülebilirliği hem de sakinliği tehdit etmektedir. Öyle ki kontrolsüz turist gelişimi Unesco Dünya Mirası alanları için de büyük tehditler arasında gösterilmektedir. Türkiye'deki sakin şehirlerin birçoğunda da özgün kültürel mirasların bulunduğu göz önüne alınırsa, Cittaslow markasının aşırı turist çekmesinin bir tehdit olarak görülmesi ve önlemlerin alınması gerektiği sonucuna varılabilir. Ayrıca yine turizm amaçlı talebi karşılamaya yönelik şehirlerde otel, pansiyon vb. tesisler inşaa edilmekte, küçük olan şehir merkezleri yayılmaya başlamaktadır. Bölge dışından gelen ziyaretçiler tarafindan arsa ve tarlalara talep artmakta ve bu bölgelere mevsimlik konutlar yapılmaktadır. $\mathrm{Bu}$ durum, betonlaşmayı artırdığı gibi yaşam alanı haline geldiği için tarım ve hayvancılık yapılacak alanların azalmasına sebep olmaktadır. Ayrıca artan talep, ev ve arsa fiyatlarında artışa sebep olmakta, bu da yöre halkı açısından yaşam şartlarını zorlaştırmaktadır. Ayrıca başka şehirlerden gelen yatırımcılar ve üst gelir grupları ile kasaba sakinleri arasında ekonomik ve kültürel farkların oluşmasına, dolayısı ile kutuplaşmaya sebep olmaktadır. Günlük hayatta yerli halka yetebilecek olan hizmeti bu durumda artan nüfusa yetiştirmek adına hizmet sektöründe çalışan ihtiyacı doğmakta bu bir yandan istihdam sağladığı için olumlu karşılansa da, insanların tarım ve hayvancılığı bırakıp yerine hizmet sektöründe çalışmaya başlaması: sürdürülebilirlik, yerel mesleklerin yaşatılması, yerel üretimin desteklenmesi gibi Cittaslow hedefleri perspektifinden bakıldığında çelişkili bir durum ortaya çıkarmaktadır. Cittaslow Felsefesi'nin doğru anlaşılamadığı takdirde karşılaşılabilecek olumsuz durumlar ve Cittaslow uygulamalarındaki çelişkileri şu şekilde özetleyebiliriz:
-Bilinirliğin artması ile yaşanan kalabalıklaşma,

•Kontrolsüz turist gelişimi ile doğanın ve kültürel varlıkların zarar görmesi,

-Şehir altyapısının karşılayabileceğinden fazla insan yüküne maruz kalmas1,

-Trafik sorunun ortaya çıkması, otopark sorunu, hava ve gürültü kirliliği,

-Yapı sayısının artması, betonlaşmanın başlaması,

-Tarımda kullanılabilecek arazilerin imara açılması,

-Artan fiyatlarla yaşamın pahalılaşması,

-İnsanlar arasında kutuplaşma yaşanması,

-Tarım ve hayvancılık sektörlerinin azalması, hizmet sektöründe artış olması,

•Halkın çalışma saatleri ve şekilleri dönüştügünden, kültürel yaşama biçimlerinin kaybolmas1,

•Sirkülasyonun fazlalığı, sakinliğin kaybedilmesi,

•Küresel ölçekli markaların yerel ürünlerin önüne geçmesi,

\section{4 Ülkemizdeki Cittaslow Yerleşimlerine Genel Bakış}

Dünyada 2021 yılı itibari ile ülkemizin de içinde olduğu 30 ülkeden 272 şehir Cittaslow resmi üyesi olmuştur. Cittaslow Hareketi'nin ülkelere göre dağılımı şekil 1 ve tablo 3'te verilmiştir. Dünyadaki Cittaslow şehirlere baktığımızda en çok üye şehrin hareketin doğduğu yer olan İtalya'da olduğu görülmektedir. Diğer şehirlerin de büyük bir kısmının Avrupa'da yer aldığını söylemek mümkündür. Tablolara bakıldığında Cittaslow şehir sayısının fazla olduğu ülkelerin ekonomik gelişmişlik düzeyine sahip olan ülkeler olduğu aşikardır. Bu anlamda Türkiye'nin dördüncü sırada olması umut verici olumlu bir durumken neden gelişmemiş ülkelerde Cittaslow üyesi olmadığı sorusu sorulabilir. Örneğin Ortadoğu ülkelerinde, Balkanlarda, Asya ülkelerinde henüz Cittaslow üyesi yoktur. $\mathrm{Bu}$ ülkelerde kriterlerinin fiziki şartlarını sağlama potansiyeline sahip birçok bölge bulunurken gelişmemiş ülkelerin veya Cittaslow Birliği'ne başvuru yapmayan şehirlerin, Cittaslow üyelik bedelini ödeyebilecek ekonomiye sahip olmadığı ya da özgünlüğünü koruyamayıp kriterleri yerine getiremediği veya içinde bulunduğu siyasi konjonktüre bağlı imkansızlıkların olduğu sonucuna varılabilir. 


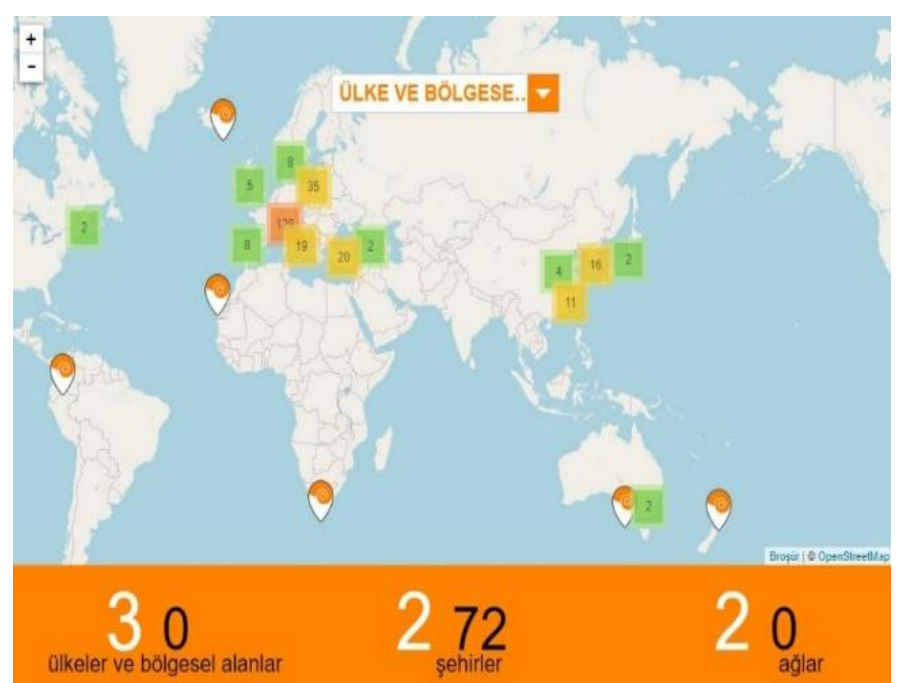

Şekil 1: Cittaslow Şehirlerin Dünyadaki Dağılımı (www.cittaslow.org, 2021)

Tablo 3: Cittaslow Şehir Sayılarının Ülkelere Göre Dağılımı

\begin{tabular}{|c|c|c|c|c|c|}
\hline İtalya & 87 & İngiltere & 5 & Japonya & 2 \\
\hline Polonya & 34 & KKTC & 5 & Finlandiya & 1 \\
\hline Almanya & 22 & Kanada & 4 & Güney Afrika & 1 \\
\hline Türkiye & 18 & Portekiz & 4 & İsveç & 1 \\
\hline Güney Kore & 16 & Tayvan & 4 & İrlanda & 1 \\
\hline Çin & 13 & Avustralya & 3 & İzlanda & 1 \\
\hline Hollanda & 11 & Avusturya & 3 & Kolombiya & 1 \\
\hline Fransa & 10 & $\mathrm{ABD}$ & 2 & Macaristan & 1 \\
\hline İspanya & 9 & Danimarka & 2 & Rusya & 1 \\
\hline Belçika & 7 & Norveç & 2 & Yeni Zelanda & 1 \\
\hline \multicolumn{2}{|c|}{ TOPLAM } & \multicolumn{2}{|c|}{30 ÜLKE } & \multicolumn{2}{|c|}{272 ŞEHÍR } \\
\hline
\end{tabular}

Türkiye'de ilk olarak 2009 yılında Seferihisar'ın sakin şehir seçilmesiyle Cittaslow Hareketi ile tanışılmıştır. Daha sonraki yıllarda Akyaka (Muğla), Yenipazar (Aydın), Gökçeada (Çanakkale) ve Taraklı (Sakarya) Perşembe (Ordu), Vize (Kırklareli), Yalvaç (Isparta), Halfeti(Şanlıurfa)'nın da sakin şehir olması ile birlikte üye sayısı dokuza ulaşmıştır. Böylece ülkemizde “Cittaslow Ulusal Ağı” kurulmuştur. Son olarak Nisan 2020'de üyeliği kabul edilen Güdül (Ankara) ilçesi ile Türkiye'de Cittaslow üyesi şehirlerin sayısı 18'e çıkmıştır. Ülkemizdeki sakin şehirler ve bulunduğu bölgeler Tablo 4'te verilmiştir. Çalışma kapsamında Türkiye'deki Sakin Şehirleri değerlendirebilmek için doğal, sosyokültürel, ve kültürel özelliklerine kısaca değinilmiştir.
Tablo 4: Türkiye'deki Sakin Şehirler

\begin{tabular}{|c|c|c|c|c|}
\hline Sira & $\begin{array}{c}\text { Türkiye'deki } \\
\text { Cittaslow } \\
\text { Yerleşimleri }\end{array}$ & \begin{tabular}{|l} 
Bağlı \\
Olduğu \\
Şehir
\end{tabular} & $\begin{array}{c}\text { Cittaslow } \\
\text { Seçildiği } \\
\text { Yıl }\end{array}$ & $\begin{array}{c}\text { Bulunduğu } \\
\text { Coğrafi } \\
\text { Bölge }\end{array}$ \\
\hline 1 & Seferihisar & İzmir & 2009 & Ege \\
\hline 2 & Akyaka & Muğla & 2011 & Ege \\
\hline 3 & Yenipazar & Aydın & 2011 & Ege \\
\hline 4 & Gökçeada & Çanakkale & 2011 & Marmara \\
\hline 5 & Taraklı & Sakarya & 2011 & Marmara \\
\hline 6 & Vize & Kırklareli & 2012 & Marmara \\
\hline 7 & Perşembe & Ordu & 2012 & Karadeniz \\
\hline 8 & Yalvaç & Isparta & 2012 & Akdeniz \\
\hline 9 & Halfeti & Şanlıurfa & 2013 & $\begin{array}{c}\text { Güneydoğu } \\
\text { Anadolu }\end{array}$ \\
\hline 10 & Şavşat & Artvin & 2015 & Karadeniz \\
\hline 11 & Uzundere & Erzurum & 2016 & $\begin{array}{c}\text { Doğu } \\
\text { Anadolu }\end{array}$ \\
\hline 12 & Göynük & Bolu & 2017 & Karadeniz \\
\hline 13 & Gerze & Sinop & 2017 & Karadeniz \\
\hline 14 & Eğirdir & Isparta & 2017 & Akdeniz \\
\hline 15 & Mudurnu & Bolu & 2018 & Karadeniz \\
\hline 16 & Köyceğiz & Muğla & 2019 & Ege \\
\hline 17 & Ahlat & Bitlis & 2019 & $\begin{array}{c}\text { Doğu } \\
\text { Anadolu }\end{array}$ \\
\hline 18 & Güdül & Ankara & 2020 & İç Anadolu \\
\hline
\end{tabular}

\section{Sürdürülebilir Şehir Yaklaşımının Önemi ve Kapsamı}

Hızlı kentleşme sebebi ile şehirler doğal ekosistemlerin yerini almaya başlamıştır. Yeryüzünde zamanla daha fazla alan kaplayan yerleşim birimleri, yeşil alanların azalmasına, doğal kaynakların hızla tüketimine, çevresel kirlenmeye ve bozulmaya, zehirli atık oluşumunda yoğunluğa sebep olmaktadır. $\mathrm{Bu}$ durum ekolojik dengenin bozulması, karbon ayak izinin artması, şehirlerde çevresel, sosyal ve ekonomik yönden sorunların artışı ile paraleldir. $\mathrm{Bu}$ noktaya gelmiş şehirler için iyileştirme, geliştirme ve planlama politikaları zorunlu hale gelmektedir. Sürdürülebilirlik kavramı, dünyadaki ekonomik ve teknolojik gelişmeler sonucu ortaya çıkan çevre sorunlarının önüne geçebilme ve ekosistemin korunması üzerine odaklanmıştır. Sürdürülebilirlik; ekonomik, sosyal, mekânsal, kültürel ihtiyaçların uyum içerisinde olduğu, toplum yararının gözetildiği, tüm kesimler için eşitlik ilkesinin esas alındığı bir kavram olarak tanımlanırken, sürdürülebilir kentleşme kavramı 
ise; ekolojik unsurlara göre şekillenen mekânsal gelişmede, bugünün ihtiyaçlarını, gelecek kuşakların ihtiyaçlarını karşılaşmasına engel olmayacak şekilde karşılamak ilkesine bağlı bir kentleşme sürecini tanımlamaktadır (Erdoğan \& Öztürk, 2019) (Anonim, 1987).

Kavramın ortaya çıkması ile birlikte sürdürülebilir kentleşmenin gelişiminde bugün ve gelecek nesillerin yaşam kalitelerinin iyileştirilmesi hedeflenerek, işsizlik sorunlarının çözümü, dengeli ekonomik gelişmenin sağlandığı, sosyal ve kültürel değerlerin korunduğu, mevcut kaynak tüketiminin sürdürülebilir kullanımını destekleyen politikalar üretilmesinin gerekliliği ortaya konulmuştur (Karakurt Tosun, 2013).

Sürdürülebilirliğin temel amacı herhangi bir yerleşim bölgesinde çevresel boyutu dikkate alarak insan ihtiyaçlarının karşılanmasını sağlamaktır. Bu ihtiyaçların karşılanması da şehirlerde birtakım düzenleyici yönetimsel planlama anlayışını gerektirmektedir. $\mathrm{Bu}$ sebeple sürdürülebilir gelişme kavramında daha çok kentlere öncelik veren politikalara sahip olduğu söylenilebilir.

Günümüz toplumsal yapısında kentlerdeki sorunlara yönelik, 1972 yılında Stockholm'de gerçekleşen BM İnsani Çevre Konferansı ile başlayan Rio Zirvesi, Gündem 21, Habitat II, Johannesburg Zirvesi gibi uluslararası toplantılarda, ekolojik sistemle kentsel süreçlerin birleştirilmesine yönelik çalışmalarla kentsel politikalar geliştirilmeye çalışılmış, 21. yüzyılda sürdürülebilir kentler oluşturmak, kentsel planlamanın temel başlıklarından biri olmuştur (Aydoğan, 2015), (Yalk1, 1997).

Literatürde kabul görmüş sürdürülebilir kentleşme ile ilgili yaklaşımlar incelendiğinde ana prensiplerin şu şekilde olduğu tespit edilebilir (Wheeler, 2013) (Yalçıner Ercoşkun, 2016) (Oktay, 2001):

Kompaktlık - Derişik Arazi Kullanımı-Bütünleşik Kent:

- Enerji ve su tüketiminin azaltılması,

- Kent dışındaki kırsal alanların, tarım arazilerinin, ekolojik türlerin korunması,

- Araç kullanımının azaltılması ile karbon ayak izinin azalmas1,

- Sosyal imkanlara kolay erişim,

- Toplumsal etkileşimin artması,

Sürdürülebilir Ulaşım- Erişilebilirlik-Araç Kullanımının Azaltılmas1:

- Yürünebilir mesafelerin ayarlanması, toplu taşıma ve bisiklet kullanımını ön plana çıkarmak,

- Yenilenebilir enerji kaynaklarını kullanmak,

- Ulaşım imkanlarına erişilebilirliğin sağlanması

Pasif Enerji Sistemleri -Etkin Kaynak Kullanımı İle Daha Az Atık Üretimi:

- İklime ve topoğrafyaya uygun yer seçimi, bina yönelimi, formu ve malzemesi

- Enerji verimliliği sağlayan yeşil bina uygulamaları,
- Bölge şartlarına göre rüzgar, güneş, su gibi kaynakların etkin kullanımı

Doğal Çevre İle Bütünleşme

- Ekolojik sürdürülebilirliğin sağlanması için yeterli yeşil alanın oluşturulması,

- Yeşil alanların toplumsal birlikteliğe imkan sağlamas1, psikolojiye ve çevreye olumlu etkisi

- Biyoçeşitliliğin korunmas1,

- Yağmur suyu yönetimine katkısı,

Sosyal Sürdürülebilirliğin Sağlanması-Çeşitlilik

- Sosyal, kamusal ve ticari aktivitelerin yan yana ve çeşitli olmas1,

- İnsanların çeşitli ihtiyaçlarını yürüme mesafesinde karşılayabilmesi,

- Bu sayede farklı tip mekanların bir arada bulunabilmesi,

- Toplumsal sınıflaşmaların azalması

Ekonominin Sürdürülebilir Olması

- Kendi kendine yeten ekonomi

- Yakın bölgelerde üretimin yapılması

- Ekonomik kalkınmanın getirdiği firsatlardan eșit bir şekilde yararlanmanın sağlanması,

Yerel Kültürün Korunmas1

- Mevcut kültürlerin çeşitliliğinin korunması,

- Kimlik, aidiyet duygusunun vurgulanmas1,

- Geleneklerin devamlılığının sağlanması.

Halkın Katılımının Sağlanması

- Halkın bilinçlendirilmesi

- Halkın yaşayacağı çevrenin oluşumunda söz hakkı olmas

\section{Geleneksel Türk Şehirlerine Genel Bakış}

Dünya genelinde olumlu bir izlenim oluşturan Cittaslow Hareketi, ülkemizde de yerel yönetimlerce oldukça ilgi görmüş ve ilki 2009 yılında Seferihisar olmak üzere, 2020 yılında Güdül’ün de listeye eklenmesiyle 18 adet şehrimiz Cittaslow ünvanı almıştır. $\mathrm{Bu}$ şehirlerin sağladığı Cittaslow kriterlerinin birbirinden farklı olduğunu görmekteyiz. Bu tüm dünya ülkeleri için de söz konusu olup, Cittaslow üyesi olmak isteyen her şehir, kendine özgü özellikleriyle bir puanlamaya tabi tutulmaktadır. Şehirler, zorunlu olan kriterleri sağlamak koşuluyla, toplamda 50 ve üzeri puan aldıkları takdirde üyeliğe kabul edilmektedirler.

Türkiye'deki Cittaslow seçilen şehirlere bakıldığında, genellikle ekonomik yapısı tarım ve hayvancıllığa bağlı, büyük şehirlere nazaran kentsel kimliğin, özgün kültürün, geleneksel ve tarihi çevrenin korunabildiği küçük şehirler olduğu görülmektedir. Geleneksel Türk Şehirleri'nde doğaya saygılı, yerel alışkanlık ve geleneklerden beslenen, malzemenin akıllıca kullanıldığı, dönemin 
şartlarına uygun sürdürülebilir çözümler barındıran bir şehirleşme anlayışı hakimdir. Bu noktada Cittaslow'un yerel sürdürülebilirlik yaklaşımı ile Geleneksel Türk Şehir yapılanmalarındaki insan odaklı tasarım anlayışının özünde birbiri ile benzeştiği ve birbirini destekler nitelikte olduğu görülmektedir. Geleneksel Türk Şehirleri'nde, yöreye özgü doğal yapı malzemesi tercihi, yerleşim birimlerinin yakınlığı, yeşil alanların mekanlardaki dağılımı, araçlardan önce insanlar için tasarlanan sokak dokusu ve yerelliğin izlerini taşıyan kimlik yapısı ile Cittaslow ünvanına sahip olmasalar dahi, doğal birer sakin şehir örneği olarak gösterilebilirler.

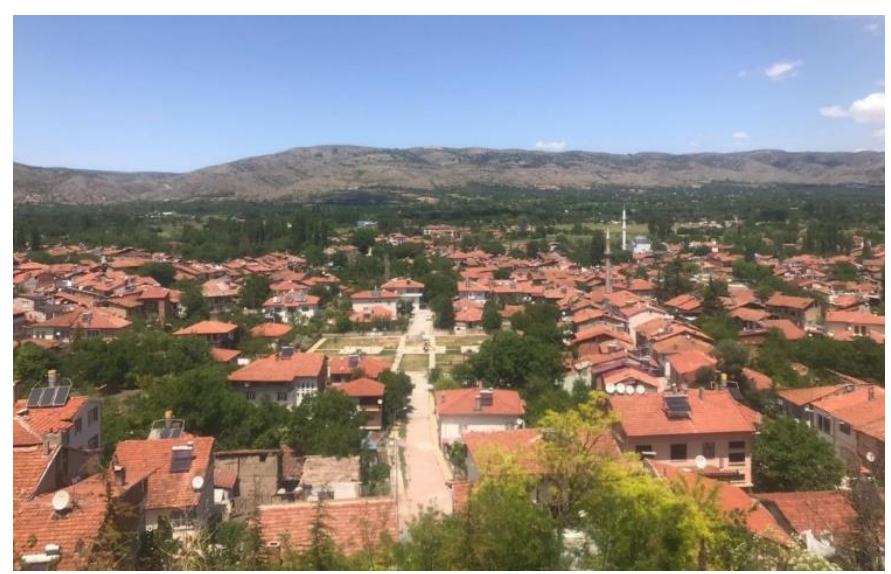

Resim 1: Geleneksel Şehir Dokusu (Tokat-Zile) (E. Ayaz Arşivi, 2021)

Ülkemizde Cittaslow seçilmeden önce de sakin olan şehirler, Cittaslow markasına sahip olduktan sonra bilinirlikleri artmakta ve olumlu bir imaja sahip olmaktadırlar. özgün destinasyonlar haline gelen bu şehirlere ilgi artmakta ve doğal olarak bu şehirlerde bir kalabalıklaşma yaşanmaktadır. Şehri ziyaret eden turist sayısındaki artış, yerel yönetimlerin ve halkın ekonomik kalkınma hedefleri için olumlu bir gelişme olmakla beraber, hızla küresel döngüye dahil olan şehirlerde turist ihtiyaçlarını karşılayabilmek için yeni birçok yapı ve tesislerin inşa edilmesini de gerekli kılmaktadır. Bu durumun kontrol altına alınamaması, Cittaslow seçilen şehirlerde, yetersiz altyap1, çevre kirliliği gibi yeni sorunlara sebep olabileceği gibi; var olan kültürel özelliklerini yitirme, artan betonlaşma ile doğal çevrenin zarar görmesi, geleneksel şehir kimliğinden uzaklaşılması ve sakinliğin kaybolması gibi tehlikeleri de beraberinde getirmektedir. Cittaslow'un yerel yönetimler ve halk tarafindan sadece ekonomik kalkınma aracı olarak görülmesi; Cittaslow'un doğal çevreyi, yerel kimliği ve kültürü koruyan, küresel homojenliğe karşı sürdürülebilir şehirler oluşturma gayesi ile çelişen durumlara sebep olabilmektedir.

5.1 Geleneksel Türk Şehirleri'nin Cittaslow Hareketine Koşut Olarak Sürdürülebilirlik Bağlamında İncelenmesi
Geleneksel Türk Şehirleri yüzyıllardır topoğrafyaya uygun, doğaya saygılı, şehrin yerel kültürle ve insanların ihtiyacından bağımsız var olamayacağı düşüncesiyle, insani değerler açısından zenginliğini koruyabilmiştir. Başka bir deyişle, geleneksel şehirler bölge halkının yaşam tarzı ve kültürünün yansımasıdır. Ülkemizde halen bu kültürün izlerini koruyabilmiş birçok şehrimiz bulunmaktadır. Fakat bu şehirler kimi zaman modern süreçlere, kimi zaman turizm sektörüne, kimi zaman da ekonomik yetersizliklere yenik düşerek zarar görmektedir. Bu şehirlerin oluşumunda çevre ve insan baş rolde olmuşlardır. Uzun yıllar süren gözlem ve tecrübe sonucunda, iklim ve topoğrafya şartlarına uygun yapım teknikleri geliştirilmiş, işlevsellik ve mümkün ölçüde estetik ön plana çıkmıştır. Dönemin ihtiyacına göre yerleşimlerin yapım teknikleri, eldeki kaynaklar kullanılarak kolay elde edilip dönüşümü sağlanabilen malzemenin kullanılmasıyla geliştirilmiştir. Dolayısı ile sürdürülebilir, çevreye duyarlı şehirlerin tasarımında şüphesiz bir örnek ve yol gösterici olarak görmek mümkündür. Geleneksel mimarinin pasif çevre kontrolündeki başarısı birçok araştırma ile ortaya çıkmış, modern sürdürülebilir şehir çalışmalarında dikkate alınmaya başlanmıştır (Oliver, 1976) (Kıstır \& Kurtoğlu, 2018). Bu çalışmanın konusunun aktörlerinden birisi olan Cittaslow Birliği de sürdürülebilir yerel kalkınmayı hedefleyen bir şehir modelidir. Ülkemizde bu modele olan ilgi oldukça yüksektir. Öyle ki dünyada birliğe üye şehir sayısı en fazla olan dördüncü ülke konumundadır. Geleneksel Türk Şehri'nin sürdürülebilir insan odaklı tasarım felsefesinin uzun yıllar boyunca şehirlerimize etki ettiği düşünülürse, bunun tesadüf eseri olmadığı görülecektir.

$\mathrm{Bu}$ bölümde yukarıda çeşitli çalışmalar yardımıyla elde edilen sürdürülebilir şehirlerin oluşmasında belirlenen ana prensiplerden yola çıkılarak, Geleneksel Türk Şehir yapılanmalarının, sürdürülebilirlik ve ekoloji ile ilişkisi ele alınmıştır.

\section{Kompaktlık - Derişik Arazi Kullanımı-Bütünleşik Kent:}

Sürdürülebilir Şehir biçimlerinin oluşmasında iyi tasarlanmış bütünleşik dokunun olumlu sonuçlarından bahsetmiştik. Türk şehrindeki organik doku da, iklime ve topoğrafyaya uygun şekilde, dar sokakların ve mahalle birimlerinin bir araya gelmesi ile oluşmaktadır. Genellikle bir cami, ya da bir çeşme veya yeşil bir meydanın etrafında kurulan; çarşı, hamam, okul, konut vb. birimlerinden oluşan, kendi kendine yeten bir yerleşim sistemi benimsenmiştir. Bitişik ya da ayrık nizam çoğunlukla avlulu evlerin, yan yana gelmesiyle biçimlenen bir sokak sistemi vardır. Arazi yapısına göre yön değiştiren sokaklar genellikle camilere, toplanma alanlarına, okullara, sosyal ve ticari alanlara bağlanmaktadır. İnsan ölçeğindeki bu bütünleşik şehir düzeni ile her işleve kolay ulaşılabilirlik sağlanmıştır. 


\section{Sürdürülebilir Ulaşım- Erişilebilirlik- Araç Kullanımının} Azaltılması: Geleneksel Türk şehrinde derişik bir sokak dokusu görülmektedir. Ulaşım, topoğrafyaya uygun geniş sokaklardan dar sokaklara doğru geçişlerin olduğu organik örüntülerle sağlanmıştır. Sokaklar insan ölçeğinde olup, konut aralarında oluşan çıkmaz sokaklar, sosyalleșme sağlayan yarı kamusal alanları oluşturmuștur. Sokakların dar olması, konutların yana yan olması sıcak iklimlerde hem güneş kontrolü sağlanarak gölgelik oluşturmakta, hem de yaya ulaşımının devamlılı̆̆ sağlanmış olmaktadır. Sokak kesişmelerine denk gelen evlerin köşeleri köşe çalığı da denilen pahlarla, insan ve yük hayvanlarının dönüşünü kolaylaştırmak için yapılmakla, yapılar ve insan arasında bir uyum sağlanmış olmakta ve yaya ve araç hareketini konforlu hale getirmektedir. Geleneksel şehrin sokaklarında hareket ederken sürekli değişen perspektiflerle görsel algıyı devamlı açı tutan bir düzen hakimdir.

\section{Pasif Enerji Sistemleri -Etkin Kaynak Kullanımı İle Daha Az} Atık Üretimi: Geleneksel Türk şehrinde etkin kaynak kullanımı şehrin inşasında başlamaktadır. Topoğrafyaya uyum, yerel malzeme kullanımı, evlerin güneşten en fazla yararlanabileceği şekilde yönlenmesi, iklime göre değişkenlik gösteren duvar kalınlıkları, yeşil alanların hemen her evin bahçesinde homojen şekilde dağılmış olması gibi prensipler şehirleşmede ilave bir enerji harcamadan nasıl doğadan faydalanılacağına en güzel örnek durumundadır. Bunun yanı sıra bugünkü enerji çözümlerine benzer olarak, yel değirmenleri, sarnıçlar, yer altına yapılan sulama kanalları, tahıl ambarları, su değirmenleri, bazı bölgelerde doğal gübre elde etmek için yapılan boranhaneler vb. sistemler örnek gösterilebilir.

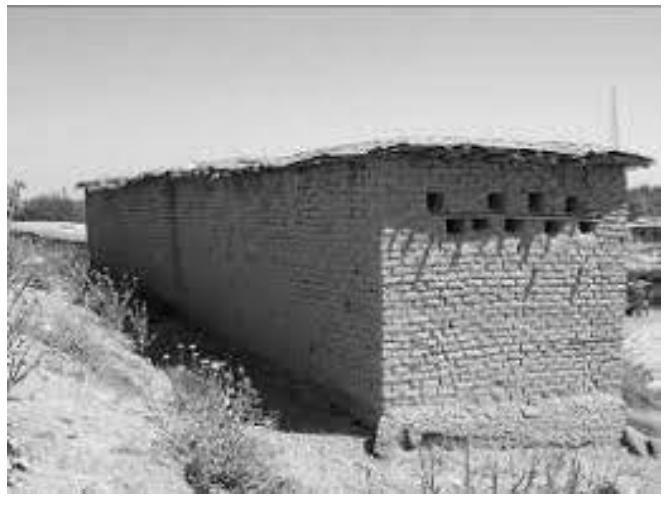

Resim 2: Diyarbakır'dan Kerpiç Boranhane Örneği (Bekleyen, 2007)

Doğal Çevre İle Bütünleşme: Geleneksel Türk Şehirleri felsefesine göre insan doğanın bir parçası olarak algılanmıştır. Mimarinin doğal çevre ile bütünleşmesinde doğa dostu tasarımın benimsenmesi de bu felsefenin ürünü olarak ortaya çıkmıştır. Birçoğu avlulu sisteme göre tasarlanan konut cami vb. mekanlarda doğa ile yakın ilişki kurulmuş açık ve kapalı mekanlar arasında aşamalı geçişler sağlanmıştır. Evlerin bahçeleri, meyve sebze yetiştirilen alanlar yerleşim yerleri arasında bugünün yeşil kuşak çalışmalarının görevini üstlenirken aynı zamanda kendi kendine yeten sürdürülebilir tarım anlayışına da örnek teşkil etmektedir. Evlerin avlularındaki ağaçlar serinliği sağlarken, güney cephe önlerine dikilen ağaçlar da güneş kontrolünü sağlamaktadır. Aynı zamanda avludaki bitkilerin yöresine özgü meyvesinden de yararlanılmaktadır. Avlularda kullanılan süs havuzları da aynı şekilde 1sıl konforun doğal yollarla sağlanmasını sağlamaktadır. Büyük gölge sağlayan ağaçlar kamusal alanda düğüm noktalarında ve şehir silüetinde bezeme ögesi olarak da büyük önem taşımışlardır. Doğa dostu tasarımda insanların konfor şartları sağlanırken diğer canlıların barınma ihtiyaçları da göz önünde bulundurulmuştur. Örneğin; Osmanlı mimarisinde sıklıkla kullanılan kuş evleri, Türk şehir mimarisinde de devam ettirilmiştir.

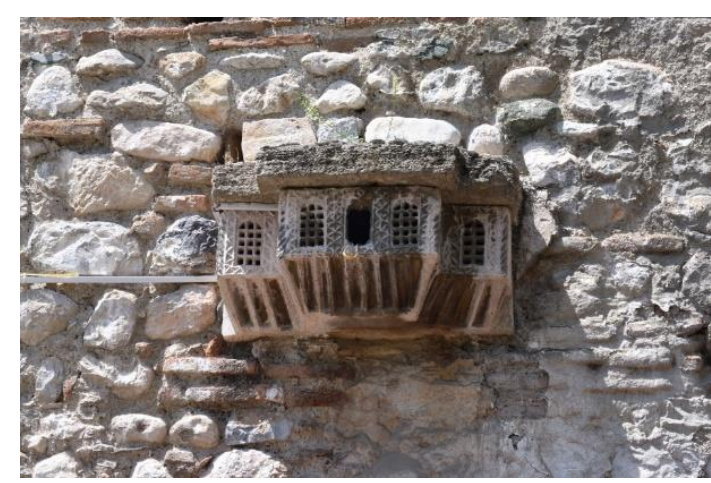

Resim 3: Tokat Zile Yeni Hamam Cephesindeki Kuş Evi Örneği (E. Ayaz Arşivi, 2021)

Sosyal Sürdürülebilirliğin Sağlanması-Çeşitlilik: Sosyal sürdürülebilirliğin kontrolü Türk Şehirlerindeki mahalle kavramı ile doğrudan ilişkili bir konudur. Geleneksel Şehrin en belirleyici özelliği etnik ve dini farklılıklara göre şekillenen mahallerden oluşmuş olmasıdır. Mahalle halkı arasındaki birlikte yaşamda ortak meslek, ticari ilişkiler, aynı köyden olma gibi durumlar da rol oynamaktadır. Bu ayrımın sınıf esaslı olmaması sosyal sürdürülebilirliğin sağlanmasında önemli bir faktördür. Her mahalle kendi içinde bir kimliğe sahip olup sosyal kontrol, yardımlaşma ve dayanışma mahalleli tarafından sağlanmıştır. Mahalleleri birbirine bağlayan organik sokak dokusu da kimi zaman çocukların evlerinin önünde oynadığı, kimi zaman kadınların zaman geçirdiği önemli bir sosyal mekan konumundadır (Aliağaoğlu \& Uğur, 2016).

Ekonominin Sürdürülebilir Olması: Türk şehirlerinde mahalleler ortak bir merkez konumundadır. Bu sebeple yerel çarşı dükkanları, imaret, atölye, cami, kahvehane vb. mekanlar, kapsamı kendi halkının ihtiyacına göre şekillenen kendi kendine yetebilen alanlar olmak durumundadır. Sosyal yaşam daha çok çarşı ve cami etrafında şekillenmektedir. Geleneksel çarşıların yeri, insanların ulaşım imkanları, merkezi olma, güvenilir olma, iklim şartları gibi etmenler 
göz önünde bulundurularak belirlenmiştir. Esnaflar arasında, günümüzdeki sistemlere göre sermaye birikimi daha az olan fakat eşitlikçi anlayışa sahip ortak bir üretim birliği vardır. Bu birliğin kendi içinde belirlediği kurallara göre ekonomik eşitlik ve sürdürülebilirlik sağlanmaktadır. Çevreye verdiği rahatsızlığa göre şehir merkezinden dışa doğru ticari mekanların yerleri belirlenmektedir. Örneğin; kitapçılar, cami yakınlarında konumlanırken kötü koku, ses ve görüntü kirliliğine sebep olabilecek tabakhane, boyahane, kazancılar gibi çarşı alanları şehrin en dış çeperinde yer almaktadır (Yalçıner Ercoşkun, 2016) (Oktay, 2001).

Yerel Kültürün Korunması: Bir şehirde sürdürülebilirliğin tam anlamıyla sağlanabilmesi yerel kültürün korunmasıyla doğrudan ilişkilidir. Bu noktada geleneksel el sanatları, geleneksel tarım kültürü, yerli malının kullanılması, kültürel birikim sonucu geliştirilen yapım tekniklerinin ve yerel malzemenin kullanımı, yerel meslek dallarının yaşatılması, korunması gereken önemli kültürel miraslardır. Geleneksel Türk şehrinde nesiller boyu bu miraslar yaşatılarak aktarılması sağlanmıştır.

Halkın Katılımının Sağlanması: Türk şehirlerinde toplumun paylaştığı ortak değerlere göre çevre oluşturulması esas alınmıştır. Yerel halk oturacağı evi ve çevresini kendi ihtiyaçlarını karşılayabilecek şekilde oluştururken, mahalle ve sokak dokusunun, komşuluk haklarının korunmasındaki sorumluluğunun da farkında olmuştur. Şehrin biçimlenişinde söz sahibi olan halk onu koruyup güzelleştirmeyi de vazife bilmiştir. Bir şehirde sürdürülebilirliğin sağlanması için yerel halkın şehir ve çevre hakkında yeterince bilgi ve sorumluluğa sahip olması gerekmektedir.

\section{Değerlendirme ve Sonuç}

90’lı yıllardan itibaren, kentlerin doğa ve insan üzerinde bırakmış olduğu olumsuz izlerin en aza indirilmesi, kentleşme baskısının kaldırılabilmesi, daha verimli ve yaşanılabilir şehirler için yeni planlama yaklaşımları geliştirilmiş ve çeşitli girişimler yapılmıştır. Bahçekent, tutumlu kent, yeşil kent, eko-kent, yaşanabilir kent, dijital kent, akıllı kent bu felsefenin girişimlerindendir. Yine 90'larda ortaya çıkan çağın getirdiği hıza, yerelliği ön plana alarak karşı gelmeyi hedefleyen Cittaslow da bu oluşumlardan birisidir. Özellikle sürdürülebilirlik, yerel ekonomi ve ekolojik şehir tasarımı anlamındaki standartlarıyla dikkat çeken Cittaslow şehirler dünyada ve ülkemizde bugüne kadar korunmuş küçük şehirlerin bir araya toplandığı bir birlik halini almıştır. Ülkemizde de küçük şehirlerde uygulanan bu hareket yerel yönetimlerin ilgisini çekmiştir. Her yaştaki, farklı kültür ve eğitimdeki inşaların sürekli en üst düzeydeki teknolojiyle iç içe yaşamasını istemek ve buna zorlamak yanlış bir karardır ve bu kararların kentsel planlamaya aktarılmasında da çeşitliliği düşünerek hareket etmek gerekir. Bu noktadan hareketle ülkemizde Cittaslow hareketinin standartlarını karşılayarak bu markaya sahip olan şehirlere bakıldığında birçoğunun geleneksel, doğası bozulmamış Geleneksel Türk şehirleri olduğu dikkat çekmektedir.

Geçmişe bakıldığında Türk şehir dokusunun bozularak bugünkü kentlerin meydana gelmesine sebep olarak gösterilen konuların başında küreselleşme, modernleşme, batıya öykünme, kaynak israfı, kimliksizleşme gibi konular gelmektedir. Küreselleşme ve modernleşmenin olumlu yönleri yadsınamaz olsa da, her bölge ve şehrin kendi kimliğini yitirmeden çağa ayak uydurması beklenmelidir. Kısacası kültürü, dokusu, geleneksel yapı sistemleri her zaman güncelliğini korumak zorundadır. Kültürün ve medeniyetin ithal edilemeyeceğini, mimarinin ve şehirleşmenin bir kültürel birikim sonucu oluştuğu ve şehirlerin ancak bu kültür birikimleri doğrultusunda tasarlanarak sürdürülebilir olacağını söylemek mümkündür.

$\mathrm{Bu}$ doğrultuda son zamanlarda dünyada olduğu gibi ülkemizde de geleneksel olanın kıymetinin geç de olsa anlaşılmaya başladığını söylemek mümkündür. Her ne kadar Avrupa kökenli bir birlik olan Cittaslow'un kriterleri ön plana çıkmış olsa da, kendi şehirlerimizde de geleneksele olan farkındalığın artmasında önemli bir rol oynamıştır.

Birçok şeyin metalaştığı, otantikliğin artık bir pazar haline geldiği, içinde bulunduğumuz kapital süreç, büyük şehirlerde istediğini elde etmiş, olumlu ve olumsuz yönleri ile birlikte küçük şehirleri de etkisi altına almaya başlamıştır. Türkiye'de, kapitalizmin tam anlamıyla ulaşamadığı, kültürel değerlerin halen yaşatıldığı, eşsiz özelliklere sahip olan, çok sayıda geleneksel şehir bulunmaktadır. Bu şehirler ekonomik kaygılar ve yok olma tehlikesine karşı daha bilinir olmak ve küresele ayak uydurabilmek adına çeşitli adımlar atmaktadır. Cittaslow ulusal bir birlik olduğundan ve kültür turizminde yönlendirici etkisi olduğundan küçük şehirlere istedikleri bu imkanı sağlamaktadır. Fakat küçük yerleşim yerlerinin turizm ekonomisinden fazlaca yararlanmak hırsıyla çok fazla adından söz ettirerek yerel özelliklerini yitirmesi gibi tehlikelerle karşı karşıya kalmaları, Cittaslow'un kendi kriterleri ile çeliştiği noktaların olduğunu göstermektedir. Kentten kaçış, doğaya özlem, köye dönüş, otantiklik gibi kavramlar Cittaslow tanımıyla yanlış kullanımlara neden olabilmektedir. Burada en önemli görev mekânsal planlamayı yapan kurumlara düşmektedir. Cittaslow kapsamındaki kentlerde mekansal planlama kararlarının doğruluğu önem taşımaktadır. Şöyle ki turizm mevsimindeki nüfusunun yerel nüfusa göre on kat fazla olduğu Cittaslow şehirleri bulunmaktadır. Bu durumda doğal kaynaklar mevsimsel olarak hızla tüketilmeye başlandığı gibi kırsal bölgeler de, artan talebe cevap verebilmek adına, hızla betonlaşarak sağlıksız büyümeye devam etmektedir. Cittaslow yerleşimlerinde bu 
büyümelerin tek başına planlı gelişme kapsamında olmasının yetmeyeceği, bina ölçeğine indirgendiğinde geleneksel yerel malzemenin ağırlıklı olduğu sürdürülebilir kentsel tasarım projelerinin olması gerektiği görülmektedir. Bu noktada Geleneksel Türk Şehir mimarisinin doğayla uyumlu, çevreye zararın minimum olduğu malzeme ve yapım tekniklerinin gelecek kuşaklara aktarılması daha da önemli hale gelmektedir. Bu sebeple zamanı tekrar gözden geçirerek geçmişteki hatalara düşülmemeli, geleneksel şehirlerdeki doğaya uygun çözümler sürdürülebilir mimarlık çalışmalarına uyarlanabilmelidir. Şehri etkileyen bir karar alınırken geçmişten gelen kültüre etkisi, şehir için riskleri ve avantajları ortaya konulmalı, öncelik ekonomik kaygılar olmamalıdır. Aksi takdirde kültürümüze ve şehir standartlarımıza aykırı olan uygulamalar günden güne artacak, korumaya çalıştığımız şehirlerimizi de küresel ekonomik kaygılar sebebi ile tamamen yok olmaya mahkum edecektir. (Ayaz, 2021)

Küresel yerel dengesini korumayı amaçlayan, ve günümüz Cittaslow Felsefesini doğru okuyabilmek için öncelikle var olan şehirlerin ihtivasındaki olmazsa olmaz standartları anlamak gerekmektedir. Yeni çevreci şehir modellerinin geliştirilmesi kapsamında uzun bir sürecin tecrübesini ve birikimini kullanmak, hızın vazgeçilmez olduğu günümüz şartlarında, doğru çözüme daha çabuk ulaşmada önemli bir ayrıntıdır.

Kısacası Uluslararası Cittaslow Hareketi, felsefesi doğru anlaşı1ıp, amaca uygun projeler geliştirildiği takdirde, geleneksel şehirlerde yaşam kalitesini iyileştirmek, şehir kültürünün ve yaşam şekillerinin sürdürülebilirliği konusunda farkındalık oluşturmak, yerel ekonomiyi güçlendirmek ve tarihi doğal çevreleri gelecek kuşaklara aktarmak noktasında iyi bir firsat sunmaktadır.

\section{Kaynaklar}

Aliağaoğlu, A., \& Uğur, A. (2016). Osmanlı Şehri. SDÜ Fen Edebiyat Fakültesi Sosyal Bilimler Dergisi, 203-226.

Anonim. (1987). Our Common Future: the Brundtland Report, World Commission on Environement and Development. Oxford University Press.

Ayaz, E. (2021). "Cittaslow YerleG̣imlerinin Kimlik ve Doku Bağlamında Değerlendirilmesi: Zile İlçesi Cittaslow Önerisi”, Yüksek Lisans Tezi, İstanbul Sabahattin Zaim Üniversitesi Lisansüstü Eğitim Enstitüsü, Mimarlık Anabilim Dalı. İstanbul.

Aydoğan, S. (2015). Sürdürülebilir Mimarlıkta Sakin Şehir Yaklaşımı. İstanbul Teknik Üniversitesi Fen Bilimleri Enstitüsün Yüksek Lisan Tezi.

Bekleyen, A. (2007). Diyarbakır Kırsalındaki Güvercin Evleri: Boranhaneler, Karaçalı (Tilalo) Köyü Trakya Univ J Sci, 8(2): 99-107.

Doğan, A. (2015). Cittaslow Hareketine Katılan Türkiye ve Dünya Kentleri. İstanbul: Atlas Yayınevi.
Erdoğan, G., \& Öztürk, B. (2019). Sürdürülebilir Kentleşme: Dokuma Kenti Buldan Örneği. Mimarlık Bilimleri ve Uygulamaları Dergisi, 51-68.

Honore, C. (2008). Yavaş.

http://seferihisar.bel.tr/. (2020, 07 16). http://seferihisar.bel.tr/: http://seferihisar.bel.tr/cittaslow-genel-baskaniseferihisarda/ adresinden alındı

https://cittaslowturkiye.org. (2020, Temmuz 20). https://cittaslowturkiye.org/uyelik-sureci-ve-kriterler/ adresinden alındı

Karakaş Özür, N. (2016). "Sakin Şehir/Cittaslow Hareketi ve Yerleşme Coğrafyası/Cittaslow Movement and Settlement Geography". SDÜ Fen Edebiyat Fakültesi Sosyal Bilimler Dergisi, 151-179.

Karakurt Tosun, E. (2013). Sürdürülebilir Kentsel Gelişim Sürecinde Kompakt Kent Modelinin Analizi . Celal Bayar Üniversitesi Yönetim ve Ekonomi.

Kistır, M., \& Kurtoğlu, D. (2018). Geleneksel Konut Mimarisinin Sürdürülebilirlik Bağlamında İncelenmesi:Ayvalık ve Oxford Evleri Örneği. Mehmet Akif Ersoy Üniversitesi Fen Bilimleri Enstitüsü Dergisi, 83-90.

Oktay, D. (2001). KENTSEL TASARIMIN KURAMSAL ÇERÇEVESINE GÜNCEL BIR BAKIŞ:KENTLERIMIZ, YAŞAM KALİTESİ VE SÜRDÜRÜLEBILLIRLİK . Mimarlik, 302.

Oliver, P. (1976). Shelter and Society . London.

Sezgin, M., \& Ünüvar, Ş. (2011). Sürdürülebilirlik ve Şehir Pazarlaması Ekseninde Yavaş Şehir. Çizgi Kitabevi Yayınları.

Toprak, M. (2018, Haziran). Cittaslow İlanı İle Sükunetini Kaybeden Şehir:Tarakl1. Mimar Sinan Güzel Sanatlar Üniversitesi Sosyal Bilimler Enstitüsü Yüksek Lisans Tezi.

Üstün Topal, T., Korkut, A., \& Kiper, T. (2016). "Yerel Kimliğin Kentle Buluşması: Cittaslow- Yavaş Şehirler". İdil Dergisi, 5(25), 5.

Wheeler, S. M. (2013). "Planning sustainable and livable cities" Sürdürülebilirlik için Planlama- Yaşanabilir, Adil ve Ekolojik Topluluklar Yaratmak. New York.

www.cittaslow.org. (2020). Cittaslow: http://www.cittaslow.org/ adresinden alınd

Yalçıner Ercoşkun, Ö. (2016). Geleneksel Türk Kentinden Sürdürülebilirlik Çıkarımları. idealkent, 522-549.

Yalk1, T. (1997). Sürdürülebilir Kent Ve Bursa 2020 Çevre Düzeni Strateji Planı - Sürdürülebilir Kalkınmanın Uygulanması Tartışma Toplantısı. Ankara: Türkiye Çevre Vakfı Yayını. 